\title{
バイオフィルムと酸化性殺菌剤；バイオフィルムモデルを用いた殺菌・除去効果評価
}

\author{
立川眞理子
}

\section{Biofilms and Oxidizing Biocides; Evaluation of Disinfection and Removal Effects by Using Established Microbial Systems}

\author{
Mariko Tachikawa \\ School of Pharmacy, Nihon University; 7-7-1 Narashinodai, Funabashi, Chiba 274-8555, Japan.
}

(Received October 31, 2016)

\begin{abstract}
The formation of bacterial biofilms and their disinfection and removal have been important subjects in the maintenance of water quality in areas such as public spas, swimming pools, food processing lines, industrial water systems, and in the hygienic control of medical devices, hospital procedures, etc. Presented here is an outline of biofilm formation, as well as studies on the disinfection and removal of biofilms by oxidizing biocides using established biofilms. These studies using established biofilms may increase the understanding of the variable response of biofilms to planktonic bacteria, and the unique aspects of oxidizing biocides in the disinfection and removal of biofilms.
\end{abstract}

Key words_— biofilms; disinfection; oxidizing biocides; chlorine; ozone; hydrogen peroxide

\section{1.はじめに}

環境において，微生物の多くは器物に付着して存 在し，水気があるところでは複数の細菌の集合体で あるバイオフィルム（biofilm）を形成している. バイオフィルムでは菌体の付着だけでなく付着基質 表面上で多糖類や菌体成分を含む細胞外ポリマーな ビからなるバイオフィルムマトリックスが形成さ れ，さらには他の微生物とも相互影響をおよぼしあ う共同的な生活空間となっている. 1) バイオフィル ムの形成は自然環境において水や土壤の浄化などに 大きな役割を果たしているが，その形成は様々な分 野において熱交換率の低下，水供給率の低下，微生 物腐食, そして微生物污染等を引き起こす原因と

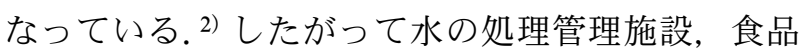
や医薬品の製造ライン, プール水や温泉水の衛生管 理, そして医療器具や病院の衛生管理などにおい て，バイオフィルムの殺菌・除去が強く求められて いる. 病院等の医療関連施設で発生する感染性疾患 の多くはバイオフィルムに起因すること, ${ }^{3)}$ バイオ

日本大学薬学部（干274-8555 千葉県船橋市習志野台 77-1)

e-mail: mrktachikawa@gmail.com

本総説は, 平成 27 年度退職にあたり在職中の業績を中 心に記述されたものである。
フィルム形成による疾患4)なども報告されている. さらにはバイオフィルムの形成により微生物の環境 変化や薬剂・殺菌剂に対する抵抗性が増すことか ら, ${ }^{2,4)}$ その制御が重要な課題となつている.

筆者らはこれまで, 水の塩素消毒に際する溶存物 質による影響, クロラミンの形成及びその反応性と 殺菌効果などについて検討を行つてきたことか ら, ${ }^{5-13)}$ それら酸化性殺菌剂のバイオフィルムに対 する殺菌・除去効果に関心を持つた。酸化性殺菌剂 の効果は微生物種による抵抗性の違いだけでなく, 水質等の環境条件にも影響を受けることから，バイ オフィルムに存在する細菌に対する各種殺菌剂の殺 菌・除去効果の検討には実際にバイオフィルムを用 いた検討が必要と考えられた。しかしながら，実際 の環境中のバイオフィルムを用いた検討は再現性が 乏しく, 繰り返しや直接の比較が困難なことが多 い. そこで数種の環境常在菌（Pseudomonas fluorescens, Pseudomonas aeruginosa, Escherichia coli) から調製したバイオフィルムモデルを用いて の種々の酸化性殺菌剂による殺菌・除去効果評価を 試みた. ${ }^{14-17)}$

本報では微生物のバイオフィルム形成及びその特 性について概説し, 次に筆者らが行つたバイオフィ ルムモデルを用いた各種ハロゲン系殺菌剤14)並びに 
オゾン水によるバイオフィルム殺菌・除去の効果評 価, ${ }^{15)}$ 及びバイオフィルムモデルを用いたオゾンと 過酸化水素の連続使用による相乗的な殺菌・除去効 果の検討, 16) そしてバイオフィルムマトリックス除 去試験の試み(17)について概要を述べ，バイオフィル ム及びその殺菌・除去効果評価に対する理解への一 助としたい.

2. バイオフィルムとは

2-1. バイオフィルムの形成バイオフィルム の形成は浮遊細菌の基質表面への接着から始まる.

基質表面は環境水中に溶存するイオンや有機物を吸 着して細菌が接着し易い状態にコンディショニング され, ${ }^{18)}$ 細菌は鞭毛や繊毛運動が加わって基質に付 着する. ${ }^{19)}$ 付着に伴い細菌の形態や生理機能が変化 し，細菌では細胞外多糖類の産生，鞭毛や繊毛運動 の低下，菌体外酵素や微生物間情報伝達物質（auto inducer；AI）の産生などが始まり，薬剤や低栄養 などの環境からの攻撃に対する抵抗性が増加す る. ${ }^{20)}$

基質に付着した細菌は基質表面上で分裂し，細胞 間の相互作用と細胞外多糖類産生によりマイクロコ ロニーを形成する。ここからさらにバイオフィルム へと成長するが，環境条件（栄養，溶存酸素，水流 など）により密度や形態が異なる. ${ }^{21)}$ 多くの場合バ イオフィルムは複数の細菌や真菌からなる微生物の 共同体であり，菌体は細胞外多糖類の分泌とともに 相互に接着して上方に伸び，水が通り易い構造 (water channel) を形成する。 ${ }^{20)}$ 緑膿菌（P. aeruginosa）の繊毛欠損株や大腸菌（E. coli）のコラン 酸（細胞外多糖類の一種）欠損株では基質表面に広 がるだけで上方に伸びるバイオフィルムが形成でき ないことが報告されている. ${ }^{20)}$ 栄養状態とバイオ フィルム構造は関連し, ${ }^{22)}$ 一般に低栄養では薄くて 基質表面にしっかりと接着したバイオフィルムが形 成し, ${ }^{23)}$ 高栄養では厚くはがれ易く，さらには菌体 が層状に積み重なつたバイオフィルムが形成し，歯 垢などはこれに属する. ${ }^{24)}$ 一方，純水システムなど でもバイオフィルムの形成は認められることから, 栄養の制限によるバイオフィルムの形成防止は困難 と考えられている. ${ }^{25)}$ バイオフィルム表面と内部で は溶存酸素濃度や $\mathrm{pH}$ が異なり，深部では嫌気的な 環境に適した細胞が優占種となり，金属腐食などを

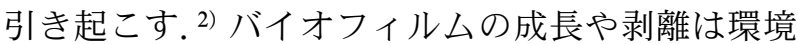

に強く影響されるが，菌体からは先に述べた AI が 分泌され，その濃度により細胞の代謝，運動性そし て菌体密度などがコントロールされていることが明 らかとなっており，クオラムセンシング（Quorum sensing）と呼ばれている. AI としてはグラム陰性 細菌では homoserine lactone 誘導体，グラム陽性細 菌では oligopeptide 誘導体，またグラム陰性菌と陽 性菌の両方が産生する furanone 誘導体が知られて いる. ${ }^{26,27)}$ また細菌が産生する界面活性物質，バイ オサーファクタントはバイオフィルム形成に関与 し，緑膿菌が産生するラムノリピッドは浮遊細菌の 付着, バイオフィルム中の水路の形成と維持及びバ イオフィルムからの菌体の離脱などに働くことが報 告されている. ${ }^{28,29)}$

基質表面の物理的な性質の違いによる菌体の接着 やバイオフィルム成長などについても検討されてい る ${ }^{19)}$ が, 細菌は基質表面のコンディショニング作用 や自身の分泌する細胞外多糖類などの助けにより種 々の基質表面への付着が可能となり，基質表面の材 料の違いによるバイオフィルム形成への影響はわず かと考えられる。 ${ }^{30,31)}$ 滑らかな表面より粗い表面の 方が付着は多い，これは粗い方が表面積は大きく， 窪みに入ったバイオフィルムは剥ぎ取られ難いため である. ${ }^{32,33)}$ 水流の強さはバイオフィルムを剥ぎ取 り成長に影響を与えるが，水流を強くしても壁面の ごく近傍になると境界層が形成し流速がほとんどな くなるため, 基質表面への細菌の付着を完全に防止 することはできない. ${ }^{19)}$ また，カルシウムイオン $\left(\mathrm{Ca}^{2+}\right)$ は細胞外多糖類に架橋し細胞外多糖類に強

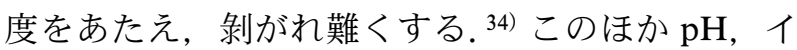
オン濃度, 温度などの環境要因によってバイオフィ ルムの形態, 成長そして剥離などが影響を受け る. ${ }^{1)}$

\section{2-2. バイオフィルムの構造と機能一細胞外高分} 子物質 (extracellular polymeric substances; EPS) の役割バイオフィルムは菌体とそれを取り囲む 細胞外マトリックスからなり立っている。 マトリッ クスの構成成分の大部分は水分 $(<97 \%)$ であり, 菌体 (2-5\%)，細胞外高分子物質 (EPS) として細 胞外多糖類 $(1-2 \%)$, 夕ンパク質 $(<1-2 \%)$, 及び DNA や RNA $(<1-2 \%)$ が存在し，そして微量の イオン類が含まれている. ${ }^{1)}$ 水は細菌の膜に結合し て存在し，またバイオフィルム内を栄養や代謝物な 
ど種々の成分を溶かし込んで流動し，バイオフィル ムの微細な構造を保持する役割を果たしている. ${ }^{35)}$ EPS の細胞外多糖類は細菌と基質，細菌同士の接 着に働き，バイオフィルムの高次構造体を維持して いる. ${ }^{36)}$ 同一株でのバイオフィルム形成時と浮遊状 態時での細胞外多糖類の組成の違いはわずかで，細 胞外多糖類はグルコースやガラクトースなどとウロ ン酸（グルクロン酸，グルロン酸そしてマンヌロン 酸など）からなる。浮遊細菌時とバイオフィルム形 成時では，アセチル化体の割合や分子の大きさが変 わることにより粘度やゲルの硬さなどが変化すると 考えられている. ${ }^{36)}$ 細胞外多糖類のほか，マトリッ クスには鞭毛や繊毛，膜小胞，細胞外酵素，及び DNA や RNA などの高分子成分とAI や有機酸 （ピルビン酸やコハク酸など）等の低分子成分が存 在し，バイオフィルムの形成と保持に働いている. それらの由来は溶菌だけでなく菌体からの分泌にも よっている. ${ }^{21)}$ 膜小胞は $\mathrm{AI}$ や酵素タンパク質の細 胞外への輸送に働き, ${ }^{37)}$ 高濃度の細胞外 DNA はバ イオフィルム構造の維持38) そして遺伝子プールとな り遺伝子の水平伝播の場をあたえる。 ${ }^{39)}$ Flemming ${ }^{31)}$ は細菌のバイオフィルム形成の利点を 以下のように挙げている。.まず基質に付着し不動な 状態でマイクロコロニーを形成し菌体同士が接着し て高密度で存在することを可能にしている，そして EPS は (1)構造の安定, (2)微生物共同体の成長, (3)濃度勾配の形成，(4)細胞外酵素の保持，(5)多糖類 と外来酵素の相互作用， (6)溶菌成分の損失防止,

(7)水路をめぐる物質の運搬, 8遺伝子プールによる 遺伝子水平伝播，9シグナル物質の交換の場の提供 など，重要な役割を担っている．次に集団となるこ とにより (1)殺菌剤，金属及び毒物に対する耐性， (2)食菌作用に対する防御，(3)複合体形成による外来 酵素に対する防御，(4)優勢生物に対する防御などを 獲得し, さらに吸着体として(1)栄養分の蓄積，(2)水 保持による乾燥防御，(3)污染物質の蓄積などの機能 を備える。

3. バイオフィルムモデルを用いた殺菌除去効果 の検討

3-1. バイオフィルムモデルの調製及び観察14-17)

筆者らはバイオフィルムの殺菌除去における種々 の殺菌剤の効果の比較検討を行うため環境常在菌の

Pseudomonas fluorescens (JCM 2779), Pseudomo-

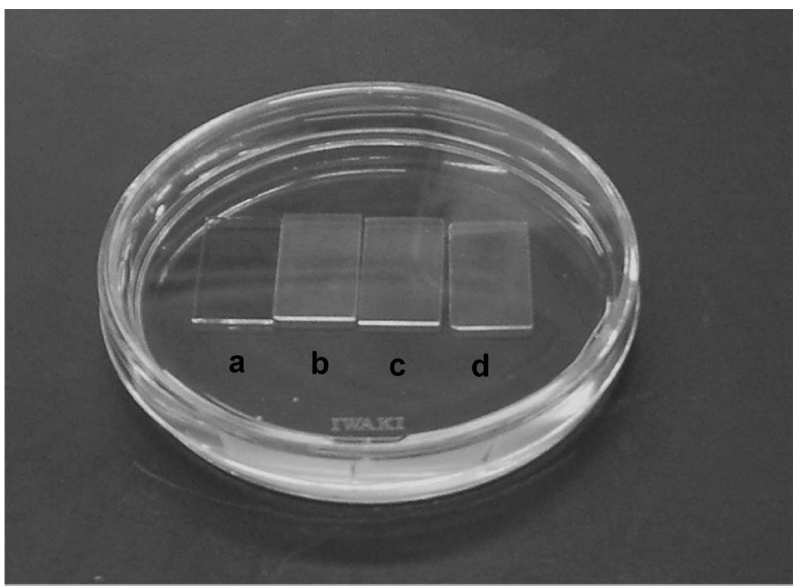

Fig. 1. Biofilm Formation of P. fluorescens on Glass Slides (b, c, d)

(a) is a glass slide before biofilm formation.

nas aeruginosa（緑膿菌，JCM 2776）及び Klebsiella pneumoniae（肺炎桿菌，JCM 1662）を用いてガ ラス小片上にそれぞれのバイオフィルム調製を試み た.

P. fluorescens 及び K. pneumoniae でのバイオ フィルムの調製にはグルコースと無機塩類からなる 培養液（G-I $)^{40)}$ を用いた。 P. aeruginosa バイオ フィルムの作製には G-I 培養液に LB 培養液 （Luria-Bertani medium）を加えて用いた。 ガラス シャーレ $(\phi 145 \mathrm{~nm})$ にガラス小片 $(1.4 \times 2.6 \mathrm{~cm})$ 16-17 枚を外縁に沿って並べ，中央にマグネット擋 汼子を置き滅菌した。 その後, 培養液 $150 \mathrm{~mL}$ と前 培養菌液 $0.3 \mathrm{~mL}$ とを加え，擋拌子をゆっくりと回 転（1 回転/秒）させながら $28 \pm 1{ }^{\circ} \mathrm{C}$ で培養し，ガ ラス小片上にバイオフィルムを形成させた。 バイオ フィルムが形成したガラス小片は生理食塩水中を 2 回通過させ，浮遊細菌を除去したのち実験に用いた。

ガラス小片上での P. fluorescens のバイオフィル ム形成は Fig. 1 に示すように, ガラス小片上の曇 りとして肉眼で観察されたが，P. aeruginosa と $K$. pneumoniae では肉眼では確認できなかった。 ガラ ス小片上に付着したバイオフィルムの生菌数を計測 したところ Fig. 2 に示すように，いずれの菌にお いてもガラス小片上に付着する生菌が認められ，バ イオフィルムの形成が示唆された。 24 時間後のガ ラス小片上に形成されたバイオフィルム中の生菌数 (cfu) は $10^{6}-10^{8}$ 個であった。培養時間が長くなる と P. fluorescens のバイオフィルムでは菌数が徐々 


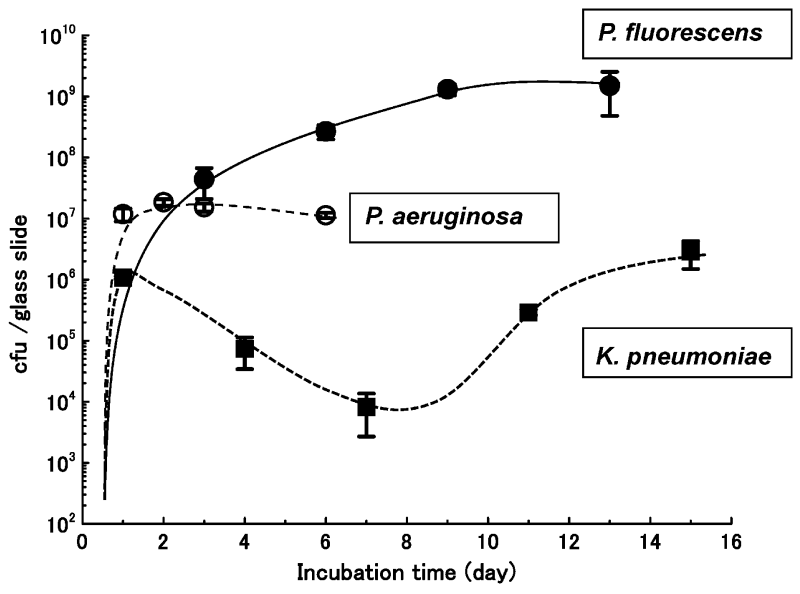

Fig. 2. Growth of Biofilms on Incubation at $28^{\circ} \mathrm{C}$

Each point, $P$. fluorescens $(\mathbf{O}), P$. aeruginosa $(\bigcirc)$ and $K$. pneumoniae $(\boldsymbol{\square})$, and bar represents mean \pm S.D. of cfu on a glass slide $(n=3-6)$.

に増加したが, P. aeruginosa のバイオフィルムで は2 日を超えるとむしろ徐々に減少した. K. pneumoniae では 1 日目には $10^{6}$ 個/小片であったが，時 間の経過とともに減少し，7日目から再び増加し た。これらガラス小片一枚あたりに付着している菌 数のバラツキは小さく, 均一なバイオフィルムを形 成していることが示唆された.

共焦点レーザー顕微鏡 [confocal laser scanning microscope (CLSM), Carl Zeiss LSM510] 観察はバ イオフィルムをLIVE / DEAD ${ }^{\circledR}$ BacLight $^{\mathrm{TM}}$ （Invitrogen 製) で蛍光染色し, 細胞膜損傷のない菌体 （緑色）と損傷のある菌体（赤色）に分けて観察し た. 焦点距離を順次変えたスキャンにより平面画像 を取り达み, コンピュータ処理により, バイオフィ ルム切断面のイメージ画像を作成した（Z stack 法)。またバイオフィルム中の多糖類層をレクチン （コンカナバリン A）抱合の蛍光色素 Alexa Fluor ${ }^{\circledR}$ 633-Con A（Invitrogen 製）で染色し，CLSM で観 察した.

3-2. ハロゲン系殺菌剤によるバイオフィルム殺 菌効果試験14) 水の衛生管理では, 大量の水に対 応でき, 作用後は無機イオンになることから, オゾ ン, 過酸化水素, 次亜塩素酸及びクロラミン若しく はブロマミン等の酸化系殺菌剤が多く用いられてき た. 中でもハロゲン系殺菌剤はその取扱いの簡易さ から, 水道のみならず, 温泉, 水泳プール等で繁用 されている. ハロゲン系殺菌剤の反応性は, ハロゲ ンの種類（塩素, 臭素及びヨウ素）で異なり, さら (a)

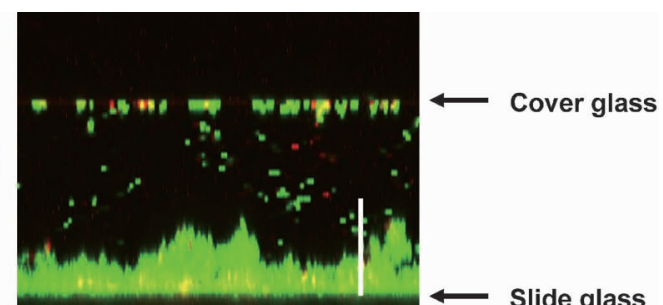

(b)

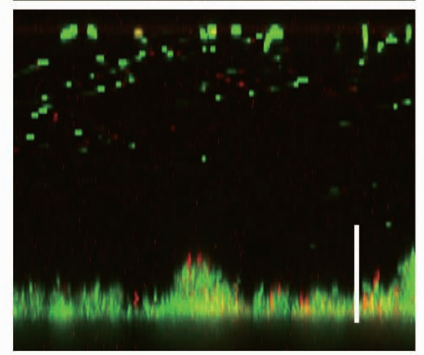

(c)

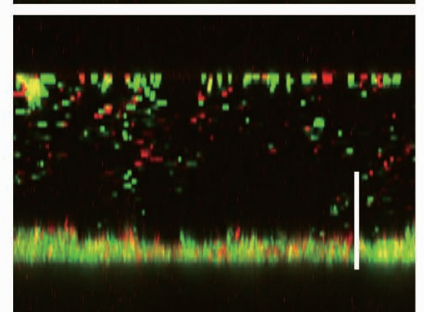

Fig. 3. CLSM Images of the Vertical Section of $P$. fluorescens Biofilms Exposed to $\mathrm{HClO}$ Solution $(1.5 \mathrm{mg} / \mathrm{L}$ as available chlorine at $\mathrm{pH} 7.4$ )

Biofilms of $P$. fluorescens formed by 24-h incubation were exposed to the $\mathrm{HClO}$ solution for indicated times. Staining and observation under the CLSM were carried out as described in the text. The bar represents $20 \mu \mathrm{m}$. (a) Control. A biofilm exposed to the medium without chlorine for $1 \mathrm{~min}$. (b) Exposed to $\mathrm{HClO}$ for $1 \mathrm{~min}$. (c) Exposed to $\mathrm{HClO}$ for $3 \mathrm{~min}$.

にそれらと結合する窒素化合物によっても異なるこ とから, ${ }^{5-7,9-13)}$ 浮遊細菌だけでなくバイオフィルム に対する各殺菌剤による殺菌・除去効果の評価がも とめられている.

このようなことから, 先に述べたバイオフィルム モデルを用いて, 数種のハロゲン系殺菌剤によるバ イオフィルムへの作用を, CLMS による観察と生 菌数測定により検討した。CLSM による観察 (Figs. 3 and 4) はバイオフィルムでの菌体の密度 や分布を明瞭に示した。 P. fluorescens バイオフィ ルムは菌体密度が高く [Fig. 3(a) ], 次亜塩素酸 $(\mathrm{HClO}$, 有効塩素濃度 $1.5 \mathrm{mg} / \mathrm{L})$ 水溶液 1 分間の 作用 $[$ Fig. 3 (b) ] では菌体の剥落が生じ，ところ ごころ膜損傷を受けた菌（赤色）が存在した. 3 分 間作用すると, 剝落は進み, 付着細菌の中にも膜損 傷を受けたものが増加していた $[$ Fig. 3(c)].P. aeruginosa バイオフィルムでは, 菌体は分散して存 在し [Fig. 4(a)], これは自ら産生する細胞外多糖 類（アルギン酸を多く含む） ${ }^{41}$ に囲まれているため 
(a)

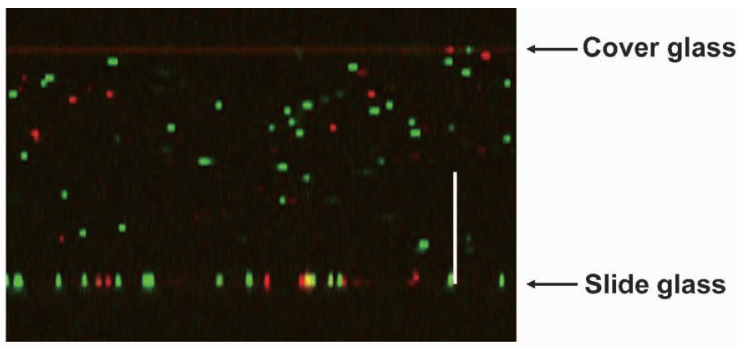

(b)

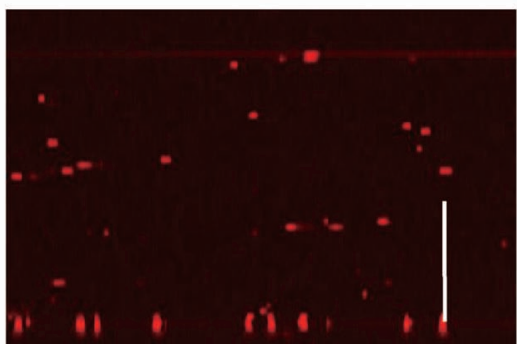

Fig. 4. CLSM Images of the Vertical Section of $P$. arerugino$s a$ Biofilm Exposed to $\mathrm{HClO}(0.8 \mathrm{mg} / \mathrm{L}$ as available chlorine at $\mathrm{pH}$ 7.4)

Biofilms of $P$. aeruginosa formed by 120 -h incubation were exposed to the $\mathrm{HClO}$ solution for $1 \mathrm{~min}$. Staining and observation under the CLSM were carried out as described in the text. The bar represents $20 \mu \mathrm{m}$. (a) Control. A biofilm exposed to the medium without chlorine for $1 \mathrm{~min}$. (b) Exposed to $\mathrm{HClO}$ for $1 \mathrm{~min}$.

と考えられた。 $\mathrm{HClO}$ 水溶液（有効塩素濃度 0.8 $\mathrm{mg} / \mathrm{L})$ を 1 分間作用すると膜損傷を受けてはいる が，剥落はほとんど生じなかった $[\mathrm{Fig} .4(\mathrm{~b})]$ 。図 では示さぬが, K. pneumoniaeバイオフィルムでは P. aeruginosa バイオフィルムに比べてさらにまば らな菌体の接着が観察された。

P. fluorescens と P. aeruginosa を用いてバイオ フィルム中の細菌とそれを分散させて調製した浮遊 細菌について $\mathrm{HClO}$ とアンモニアクロラミン
$\left(\mathrm{NH}_{2} \mathrm{Cl}\right)$ による殺菌効果を比較した（Table 1). いずれの菌においても $\mathrm{NH}_{2} \mathrm{Cl}$ の浮遊細菌に対する 殺菌効果は $\mathrm{HClO}$ に比べて明らかに劣るが，バイ オフィルム細菌に対しては $\mathrm{NH}_{2} \mathrm{Cl}$ は $\mathrm{HClO}$ とほぼ 同等の効果を示した。 P. fluorescens においてはバ イオフィルム形成による $\mathrm{HClO} へ$ の抵抗性の著し い増加が示され，バイオフィルムに対しては浮遊細 菌に対する殺菌効果をそのまま適用できないことが 示唆された.

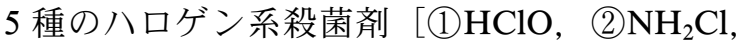
(3)ブロムクロルジメチルヒダントイン $(\mathrm{Br}, \mathrm{Cl}-$ $\mathrm{DMH}$ ，水中では一部解離して $\mathrm{HBrO}$ と $\mathrm{HClO}$ を生 じる)，(4)スタブレックス（STABREX，主成分は ブロムスルファミン酸 $\mathrm{BrNHSO}_{3} \mathrm{H}$ ) 及び(5)ブロム クロラミン $\left(\mathrm{NH}_{4} \mathrm{Br}+\mathrm{HClO}\right.$, 主成分は $\mathrm{NHBrCl}$ と $\mathrm{NH}_{2} \mathrm{Cl}$ の混合物 ${ }^{14)}$ ] による $P$. fluorescens バイオ フィルムに対する殺菌効果を検討し，各殺菌剤水溶 液の作用時間毎の生残率を Fig. 5 に示した. $\mathrm{NH}_{2} \mathrm{Cl}$ 水溶液及び $\mathrm{NH}_{4} \mathrm{Br}$ と $\mathrm{HClO}$ との混合水溶液では作 用時間中持続した生残率の低下を示したが， $\mathrm{HClO}$ 水溶液と $\mathrm{Br}, \mathrm{Cl}-\mathrm{DMH}$ 水溶液では作用初期で生残 率の低下が観察されたが，その後生残率は横ばいと なって殺菌効果の低下が生じた。この原因として酸 化力の高い $\mathrm{HClO}$ や $\mathrm{HBrO}$ はマトリックス成分と 反応しバイオフィルム中への浸透が進まないことが 考えられた。 それに対し $\mathrm{NH}_{2} \mathrm{Cl}$ や $\mathrm{NHBrCl}$ の低い 反応性（安定性）が浸透性と重なり持続した殺菌効 果を示したと考えられた。

3-3. オゾン水によるバイオフィルム殺菌効果 ${ }^{15}$ オゾンは強い酸化性を持ち, 水処理において水中

Table 1. Comparison of the Biocidal Efficacy of $\mathrm{HClO}$ and $\mathrm{NH}_{2} \mathrm{Cl}$ on Suspended and Biofilm Cells of P. fluorescens and $P$. aeruginosa

\begin{tabular}{|c|c|c|c|c|c|c|}
\hline \multirow{3}{*}{ Microorganisms } & \multirow{3}{*}{ Chlorine } & \multicolumn{5}{|c|}{$\mathrm{cfu} /$ plate $\left(\times 10^{6}\right)$} \\
\hline & & \multirow{2}{*}{ Control } & \multicolumn{2}{|c|}{ Biofilm cells } & \multicolumn{2}{|c|}{ Suspended cells } \\
\hline & & & Treated & $\%^{a}$ (std.) & Treated & $\%^{a}$ (std.) \\
\hline \multirow[t]{3}{*}{ P. fluorescens } & $\mathrm{HClO}$ & 224 & 0.88 & $0.39(0.39)$ & 0.35 & $0.16(0.14)$ \\
\hline & $\mathrm{HClO}$ & 704 & 44.7 & $6.35(0.17)^{*, b}$ & 5.29 & $0.75(0.65)^{*, \mathrm{~b}}$ \\
\hline & $\mathrm{NH}_{2} \mathrm{Cl}$ & 742 & 51.2 & $6.90(5.60)$ & 25.0 & $3.37(0.32)$ \\
\hline \multirow[t]{2}{*}{$P$. aeruginosa } & $\mathrm{HClO}$ & 20.3 & 0.088 & $0.43(0.08) * *, \mathrm{~b}$ & 0.0015 & $0.01(0.005)^{* *, \mathrm{~b}}$ \\
\hline & $\mathrm{NH}_{2} \mathrm{Cl}$ & 13.1 & 0.079 & $0.60(0.41)$ & 0.0104 & $0.08(0.13)$ \\
\hline
\end{tabular}

Since the suspended cells were prepared by ultrasonic dispersion of the biofilm formed in an aliquot volume of $0.5 \mathrm{~mm}$ phosphate buffer solution at $\mathrm{pH}$ 7.4, the number of control cells was common between the biofilm and suspended cells in the same line. The cells were exposed to the chlorine solutions of $1.7-2.4 \times 10^{-5} \mathrm{M}$ as available chlorine at $\mathrm{pH} 7.4$ for $5 \mathrm{~min}$. Significant difference was examined by Student's $t$-test $(n=3)$. a $(\mathrm{cfu}$ treated $/ \mathrm{cfu}$ control $) \times 100{ }^{\mathrm{b}}$ Significant difference $(p<0.05)$ between the same numbers of asterisks. 


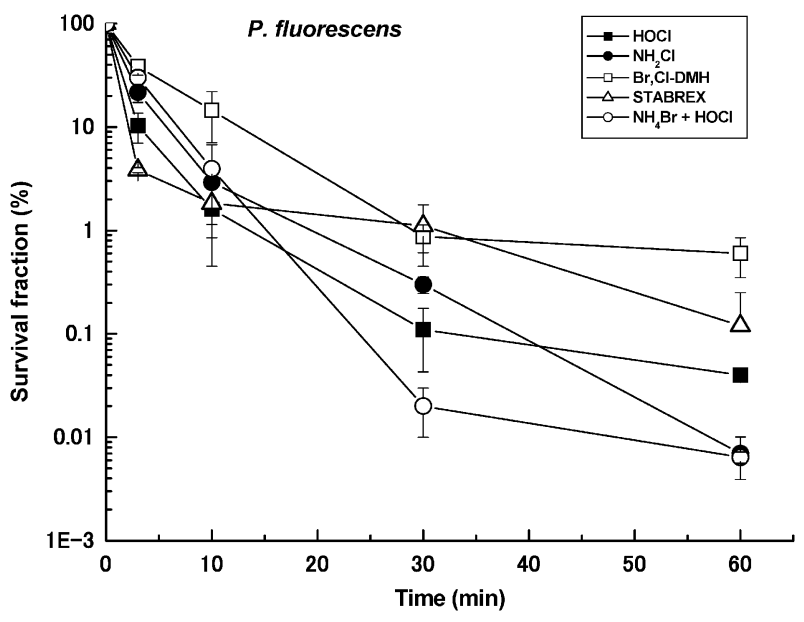

Fig. 5. Efficacy of Several Biocides on the Biofilms of $P$. fluorescens

The biofilms were exposed to the biocide solutions of $2.1-2.9 \times 10^{-5} \mathrm{M}$ as available halogen at $20^{\circ} \mathrm{C}$ for indicated times. The $\mathrm{pH}$ of the test solutions was 7.4 and that of the mixed solution of $\mathrm{NH}_{4} \mathrm{Br}$ and $\mathrm{HClO}$ was 8.5. Each point represents the mean value of 3 plates.

溶存物質の分解や殺菌に用いられており, バイオ フィルムに対する殺菌効果についての検討が求めら れていた。

オゾン水は電解式オゾン水生成器（アイ電子工業 製，AOD-TH）に活性炭フィルターを通して残留 塩素を除いた船橋市水道水を通して調製した。オゾ ン水の半減期は数分 ${ }^{42)}$ と短いので, ガラス小片上の バイオフィルム表面に直接水流が当たらないように 工夫したガラス製の曝露装置（試験槽容量は 500 $\mathrm{mL}$, 試験水流速は通常 $25 \mathrm{~mL} / \mathrm{s}$ ) を作製し, 流水 式での検討を行った。

P. fluorescens と P. aeruginosa から調製したバイ オフィルムを少量の滅菌水中で超音波処理して得た 菌浮遊液とバイオフィルムについて，バッチ式でオ ゾン水 $(1.6-1.7 \mathrm{mg} / \mathrm{L})$ を 5 分間曝露させたときの
生残率を求めた（Table 2)。浮遊細菌に対するバイ オフィルム細菌の生残率の比は P. fluorescens では およそ 4000，P. aeruginosa ではおよそ 20 であ り，いずれの菌においてもバイオフィルム細菌の抵 抗性は菌浮遊液に比べて増加していた。 $P$. fluorescens バイオフィルムでのオゾン水に対する抵 抗性の増加比は, 前章での $\mathrm{HClO}$ での抵抗性の増 加比よりも著しかった.

P. fluorescens と P. aeruginosa のバイオフィルム について，流水式で水道水及び種々の濃度のオゾン 水に曝露し，曝露時間毎の生残率を調べた (Fig. 6). P. fluorescens ではオゾン濃度 $0.92 \mathrm{mg} / \mathrm{L}$ と 1.35 $\mathrm{mg} / \mathrm{L}$ では生存率にはほとんど差がなかったが, $3.2 \mathrm{mg} / \mathrm{L}$ になると曝露時間に伴う生残率の減少が 観察された [Fig. 6(a)]。P. aeruginosa のバイオ フィルムではオゾン濃度 $1.30 \mathrm{mg} / \mathrm{L}$ を超えると生 残率の著しい減少が観察された。低濃度のオゾン水 曝露では曝露時間が長くなるにつれて生残率の低下 は遅くなり，バイオフィルム構成成分とオゾンとの 反応により浸透阻害が生じていることが考えられ た. ハロゲン系殺菌剤と同様にオゾン水によるバイ オフィルムの殺菌・除去効果は曝露時間とは比例せ ず，従来の浮遊細菌での効果評価に用いられる CT 值（Concentration $\times$ Time） は適用できないことが 示された。

オゾン水作用（1.2-1.1 mg/L， 1 分間）後の CLSM による観察では, P. fluorescens バイオフィ ルムではバイオフィルム層の剥落，P. aeruginosa バイオフィルムではアルギン酸層が薄くなり，層中 の菌体の膜損傷を受けている割合が増加していた.

バイオフィルムを形成する細胞外多糖類に対する オゾン水の作用について CLSM により検討した.

Table 2. Disinfection Efficacy of Ozone Water on Biofilm and Suspended Cells of $P$. fluorescens and P. aeruginosa in a Batch Treatment for 5 Min

\begin{tabular}{|c|c|c|c|c|c|c|}
\hline \multirow{2}{*}{ Microorganisms } & \multicolumn{3}{|c|}{$\begin{array}{l}\text { Biofilm cells } \\
\text { cfu/plate }\left(\times 10^{6}\right)\end{array}$} & \multicolumn{3}{|c|}{$\begin{array}{l}\text { Suspended cells } \\
\mathrm{cfu} / \text { suspension }\left(\times 10^{6}\right)\end{array}$} \\
\hline & $\mathrm{O}_{3}(\mathrm{mg} / \mathrm{L})$ & Treated & $(\%)^{b}$ & $\mathrm{O}_{3}(\mathrm{mg} / \mathrm{L})$ & Treated & $(\%)^{b}$ \\
\hline \multirow[t]{2}{*}{ P. fluorescens } & control & $159 \pm 26$ & & & & \\
\hline & 1.7 & $36.1 \pm 24.7$ & $22.7 \pm 15.5$ & 1.5 & $0.009 \pm 0.012$ & $0.006 \pm 0.008$ \\
\hline \multirow[t]{2}{*}{ P. aeruginosa } & control & $23.8 \pm 9.7$ & & & & \\
\hline & 1.6 & $0.03 \pm 0.01$ & $0.13 \pm 0.04$ & 1.4 & $0.002 \pm 0.001$ & $0.008 \pm 0.004$ \\
\hline
\end{tabular}

Mean \pm S.D. $(n=3)$. a Suspended cells were obtained by ultrasonic dispersion of biofilms established on glass plates prepared at the same time as described in experiments precisely. Therefore, the control fractions of biofilm and suspended cells are containing the same number of cfu, respectively. ${ }^{b}(\mathrm{cfu}$ treated $/ \mathrm{cfu}$ control $) \times 10$. 

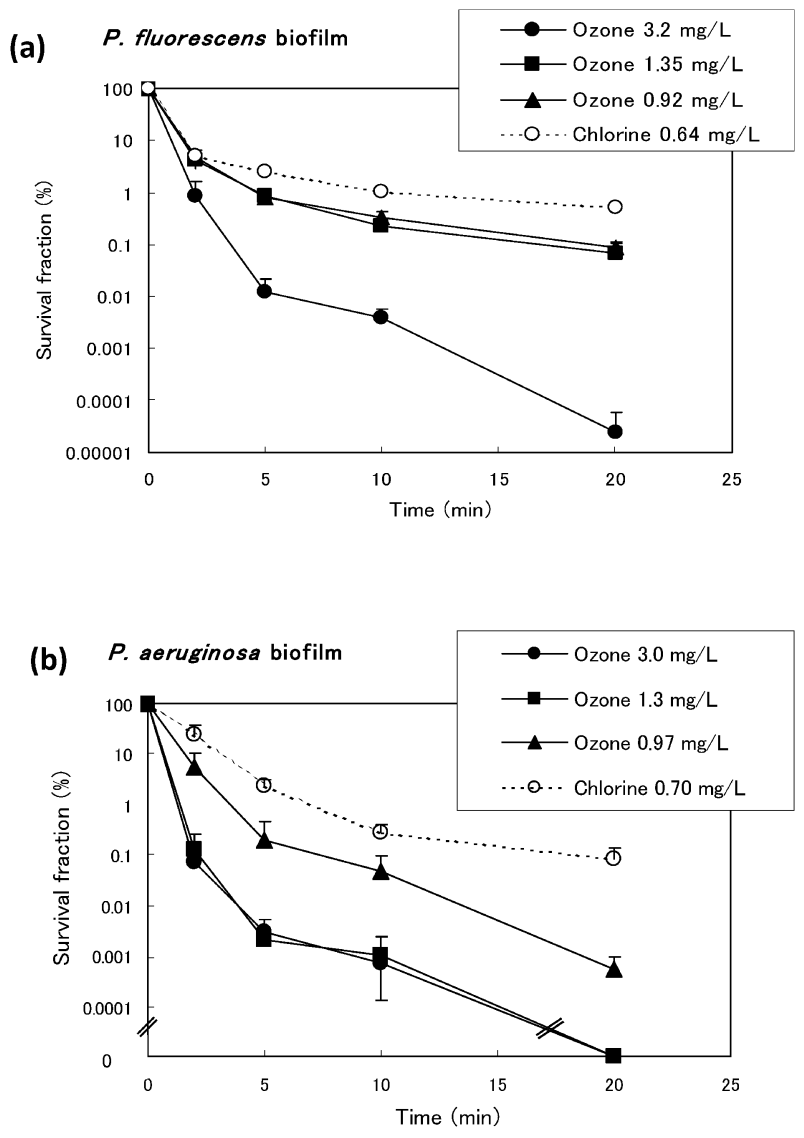

Fig. 6. Efficacy of Ozone Water (ozone, $\boldsymbol{O}, \boldsymbol{\Delta}$ and $\boldsymbol{\square}$ ) and Chlorinated Tap Water (free chlorine, $O$ ) on the Biofilms of $P$. fluorescens (a) and P. aeruginosa (b) Treated in the Flow-through System at Indicated Ozone Concentrations Each point with a bar represents the mean cfu value and S.D. of 3 slides.

P. fluorescens バイオフィルムにオゾン濃度を変え て（1 及び $2 \mathrm{mg} / \mathrm{L}) 10$ 分間作用させ，曝露後にガ ラス小片上に残る細胞外多糖類をレクチン抱合蛍光 色素で染色し CLSM で観察した (Fig. 7)。ガラス 小片には細胞外多糖類の付着がみとめられ，オゾン 濃度が高くなると残存する細胞外多糖類は減少し, オゾンによる細胞外多糖類の酸化分解が示された. Figure 6 との結果を考え合わせると，P. fluorescens バイオフィルムの効果的な殺菌・除去には細胞外多
糖類の分解が生じるオゾン濃度が必要であると考え られた。

3-4. バイオフィルム殺菌除去に対するオゾン水 之過酸化水素水の連続暴露による相乗効果 ${ }^{16)}$ 前 章において，オゾン水によるバイオフィルムの殺菌 において低濃度 (1-2 mg/L) では浸透阻害が生じ, オゾン濃度を高くして細胞外多糖類の分解を進める ことが必要であることが示唆された。そこでより強 い酸化力を持つヒドロキシラジカル $(\cdot \mathrm{OH})$ を生 成するオゾンと過酸化水素の混合による促進酸化法

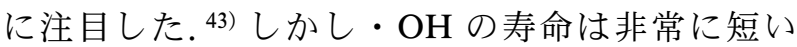
(半減期 : $\left.10^{-7} \mathrm{~s}\right)^{42}$ ことから, 通常の水処理で用い られるオゾン水と過酸化水素水の混合によるバイオ フィルム曝露ではなく, 器物表面に付着するバイオ フィルム上（若しくはバイオフィルム中）での ・ $\mathrm{OH}$ 生成を目的として，バイオフィルムへのオゾ ン水と過酸化水素水の連続的な曝露を検討した.

Figure 8 に示すように，オゾン水と過酸化水素水の 曝露順序を変えて P. fluorescens のバイオフィルム に連続的に曝露し, 生残率を検討した. Figure 8 中 の点線はオゾン水と過酸化水素水のそれぞれの単独 曝露（Aと B）により得られた生残率の積である. 過酸化水素水 $\rightarrow$ オ゙ン水の連続曝露（C）ではそれ ぞれにおける生残率の相加的な効果であったが，才 ゾン水 $\rightarrow$ 過酸化水素水の連続曝露（D）では生残率 が著しく低下し相乗的な殺菌効果が認められた。曝 露（D）と同条件で過酸化水素中に殺菌には影響を 及ぼさない濃度のメタノール（1％）を添加すると 相乗効果が弱まり，・OH 生成による促進効果と考 えられた。曝露の順序を変えて曝露したバイオフィ ルムについて菌体と，細胞外多糖類の蛍光染色を行 いCLSM により観察を行った（Fig. 9)。オゾン水 $\rightarrow$ 過酸化水素水の連続曝露 [Fig. 9(b) ] ではバイ オフィルムを構成する細胞外多糖類や菌体が浮き上 がった様子を示しており，この連続曝露によりバイ

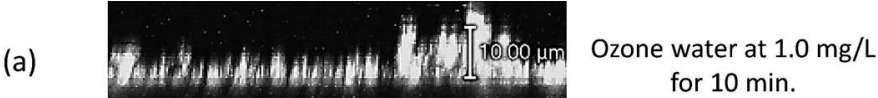 \\ (b)

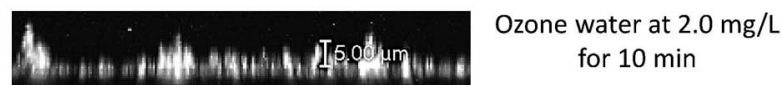

Fig. 7. Decrease of Extracellular Polysaccharide in the P. fluorescens Biofilm Matrix by Treatment with Ozone Water Extracellular polysaccharide attached on the glass slide was stained with concanavalin A, Alexa Fluor ${ }^{\circledR} 633$ conjugate after the treatment. The bars represent 10 $\mu \mathrm{m}$ in (a) and $5 \mu \mathrm{m}$ in (b) . 


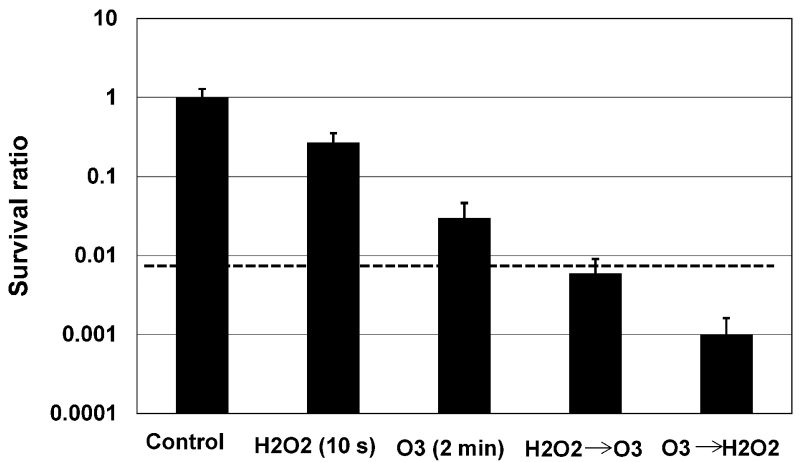

(A)

(B)

(C)

(D)

Fig. 8. Disinfection Efficacy of $\mathrm{H}_{2} \mathrm{O}_{2}$ and $\mathrm{O}_{3}$ in Their Single and Sequential Two-step Treatments of the Biofilms of $P$. fluorescens

(A) Biofilms were treated with $\mathrm{H}_{2} \mathrm{O}_{2}$ for $10 \mathrm{~s}$; (B) treated with $\mathrm{O}_{3}$ for 2 min; (C) treated first with $\mathrm{H}_{2} \mathrm{O}_{2}$ for $10 \mathrm{~s}$ followed by $\mathrm{O}_{3}$ for $2 \mathrm{~min}$; (D) first with ozone for $2 \mathrm{~min}$ followed by $\mathrm{H}_{2} \mathrm{O}_{2}$ for $10 \mathrm{~s}$. The concentrations of $\mathrm{O}_{3}$ and $\mathrm{H}_{2} \mathrm{O}_{2}$ were $1.3 \mathrm{mg} / \mathrm{L}$ and $1.1 \%$, respectively. Survival ratios were expressed as means \pm S.D. $(n=3)$. The dotted line indicates an estimated additive survival ratio of $\mathrm{H}_{2} \mathrm{O}_{2}$ and $\mathrm{O}_{3}$, obtained by multiplying the survival ratio of $\mathrm{H}_{2} \mathrm{O}_{2}$ (A) by that of $\mathrm{O}_{3}(\mathrm{~B}) ; 0.27 \times 0.03=0.0081$.

オフィルムの剥離や菌体損傷が増加していた。 また この現象はバイオフィルム底部から観察されること から，殺菌剤のバイオフィルムへの浸透が示唆され た。オゾンの曝露温度を下げる $\left(25^{\circ} \mathrm{C} \rightarrow 8^{\circ} \mathrm{C}\right)$ と相 乗効果は強まり, オゾンのバイオフィルム浸透の増 加よりバイオフィルム中での・ $\mathrm{OH}$ 生成が増加した
ためと考えられた．オゾン 過酸化水素曝露により 細胞外多糖類の分解が進んでいることから，バイオ フィルムの殺菌・除去における細胞外多糖類, さら には細胞外高分子物資 (EPS) の分解の重要性が強 く示唆される結果であった。また，ここで示した殺 菌剤の連続処理による殺菌効果の増強はバイオフィ ルム殺菌に対する新手法を提案するものと考えられ る.

3-5. 酸化性殺菌剂によるバイオフィルムマト リックスの分解除去 ${ }^{17)}$ 前章からもバイオフィル ムの制御には殺菌のみならずバイオフィルムマト リックスの分解・除去が重要であることが示唆され たことから, オゾン水, 次亜塩素酸ナトリウム $(\mathrm{NaClO})$ 水溶液及び過酸化水素 $\left(\mathrm{H}_{2} \mathrm{O}_{2}\right)$ 水溶液に よるマトリックス分解除去効果について比較検討し た.

P. fluorescens と E. coli のバイオフィルムはそれ ぞれ G-I 培養液40) と LB 培養液を用いて 24 穴のマ イクロプレートに調製した。 バイオフィルムを形成 したマイクロプレートは培地を捨て超純水で濯いだ 後，それぞれの試験水中に一定時間浸した。 $0.01 \mathrm{M}$ チオ硫酸ナトリウム水溶液に浸けて中和したのち, マイクロプレートに残る EPS 量をクリスタルバイ (a)

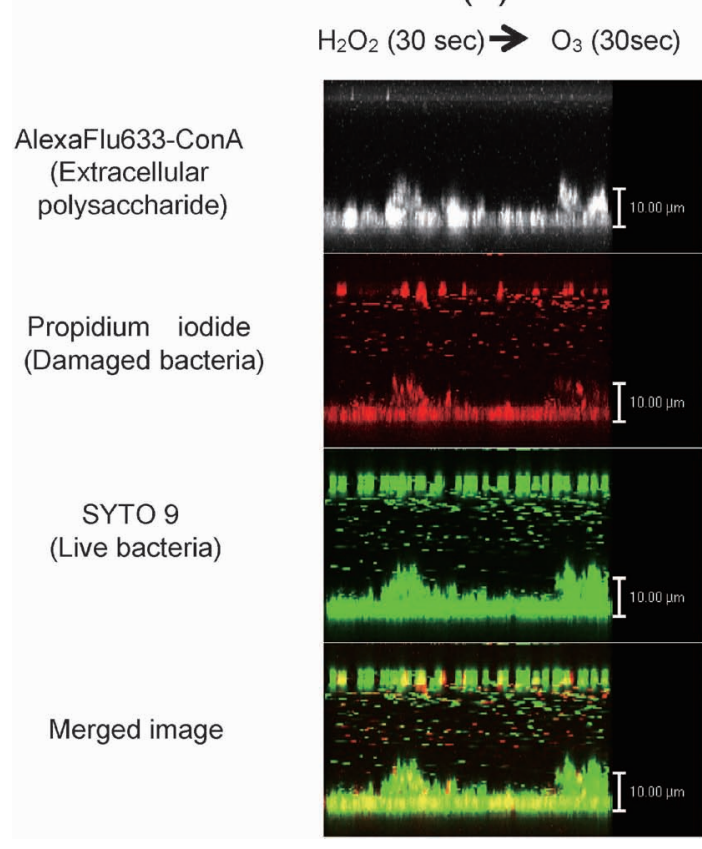

(b)

$\mathrm{O}_{3}(30 \mathrm{sec}) \rightarrow \mathrm{H}_{2} \mathrm{O}_{2}(30 \mathrm{sec})$

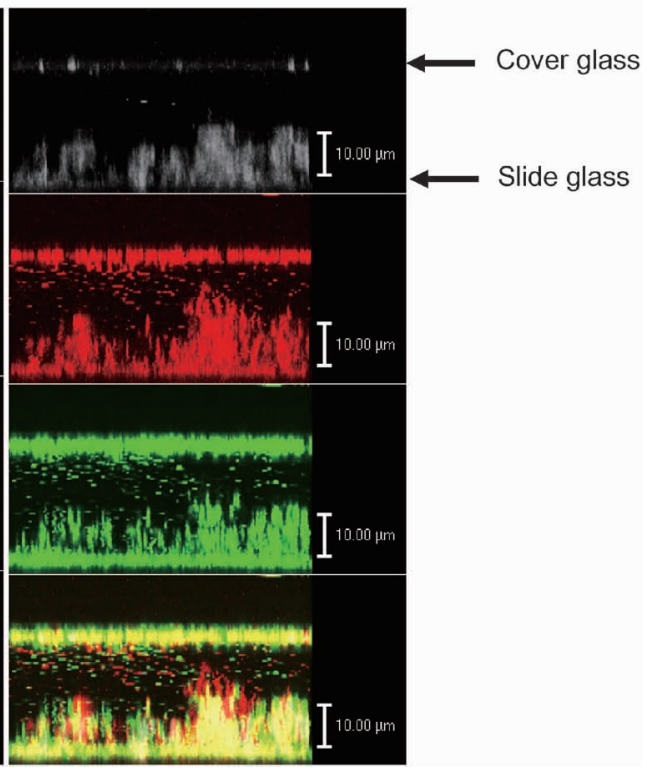

Fig. 9. Observation of the Biofilms of $P$. fluorescens Treated with $\mathrm{O}_{3}$ and $\mathrm{H}_{2} \mathrm{O}_{2}$ Sequentially by CLSM after Staining with Alexa Fluor $^{\circledR}$ 633-Con A, and Live/Dead BacLight ${ }^{\mathrm{TM}}$, an Equal Volume Mixture of Propidium Iodide and SYTO 9 Solutions

(a) Biofilms were first treated with $\mathrm{H}_{2} \mathrm{O}_{2}$ for $30 \mathrm{~s}$ followed by $\mathrm{O}_{3}$ for $30 \mathrm{~s}$; (b) first with $\mathrm{O}_{3}$ for $30 \mathrm{~s}$ followed by $\mathrm{H}_{2} \mathrm{O}_{2}$ for $30 \mathrm{~s}$. The concentrations of $\mathrm{O}_{3}$ and $\mathrm{H}_{2} \mathrm{O}_{2}$ were $1.2 \mathrm{mg} / \mathrm{L}$ and $1.1 \%$, respectively. The bars represent $10 \mu \mathrm{m}$. 
P.fluorescens

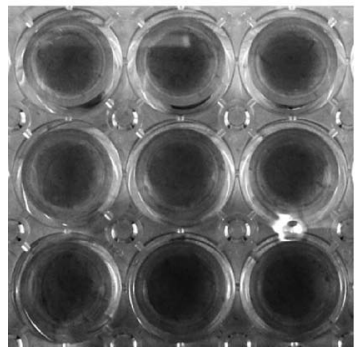

E. coli

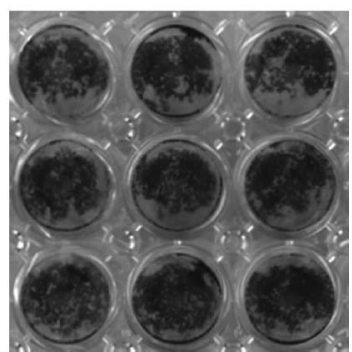

Fig. 10. Crystal Violet (CV) Staining of Biofilm Matrices of $P$. fluorescens (a) and E. coli (b) Formed in 24-Well Microplates

Biofilms of $P$. fluorescens were prepared in glucose-mineral growth medium ${ }^{40)}$ for $24 \mathrm{~h}$ incubation at $30^{\circ} \mathrm{C}$, and those of $E$. coli were in diluted $\mathrm{LB}$ medium for $48 \mathrm{~h}$ at $30^{\circ} \mathrm{C}$. After the incubation, growth medium in wells were discarded and the matrices formed in wells were rinsed with water and dried, then followed by staining with $0.1 \% \mathrm{CV}$ solution for $30 \mathrm{~min}$. Excess $\mathrm{CV}$ on matrix was washed out with water and the matrix in wells were air dried.

オレット（CV） 染色により測定した. ${ }^{44,45)}$ それぞ れのマトリックスに吸着した CV を 70\%エタノー ル水溶液で溶出し, 溶出液の $595 \mathrm{~nm}$ での吸光度 $\left(\mathrm{C}_{\mathrm{t}}\right)$ を求めた。酸化剂水溶液の代わりに純水を用 いたときの吸光度 $\left(\mathrm{C}_{0}\right)$ を対照とし, その比 $\left(\mathrm{C}_{\mathrm{t}} /\right.$ $\mathrm{C}_{0}$ ）をマトリックス残留率とした.

調製した各バイオフィルムマトリックスの CV 染 色像を Fig. 10 に示した. P. fluorescens のマトリッ クスは CV で均一に染色（実際は青色）され，大腸 菌のマトリックスはやや不均一でウロコ状に染色さ れ，両者のバイオフィルム構造の違いが示唆され た. 両バイオフィルムマトリックスに対するオゾン 水による除去効果を Fig. 11 に示した. グルコース を主成分とする培地で調製した P. fluorescens のマ トリックスはオゾン水 $(2.7 \mathrm{mg} / \mathrm{L})$ によりプレー トからの剥離が進み 30 分後にはほぼ消失した。一 方ペプトンを主成分とする培地で調製した E. coli のマトリックスの分解には高濃度 $(10 \mathrm{mg} / \mathrm{L})$ を要 し，マトリックス構造と組成の違いにより除去効果 は大きく影響を受けることが示唆された。 $\mathrm{NaClO}$ 水溶液では 1000-1500 mg/L で分解・除去が観察さ れ, $\mathrm{H}_{2} \mathrm{O}_{2}$ 水溶液（室温）では濃度 $1 \%$ でもマト リックス除去効果は得られなかった。 これらのこと から，酸化性殺菌剂によるマトリックス除去には殺 菌に比べ高濃度を要することが示された。

\section{4. まとめ}

本報ではバイオフィルムとそのマトリックスの形

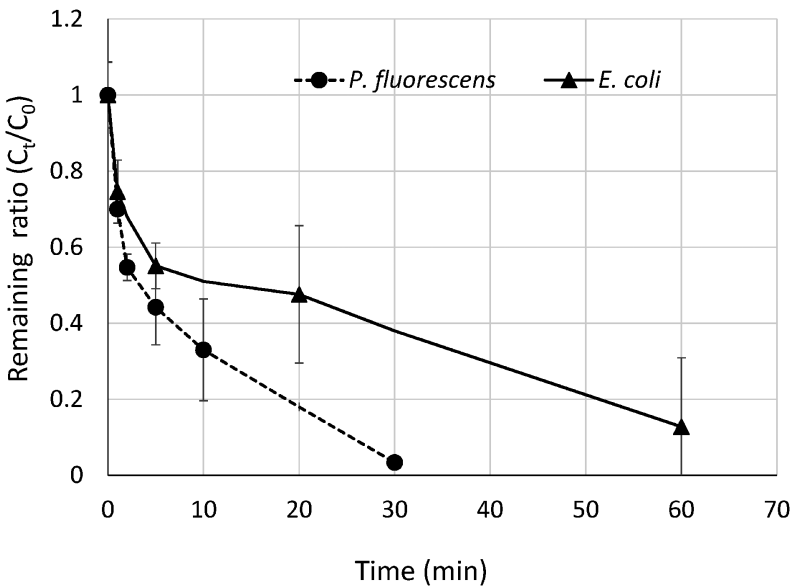

Fig. 11. Removal of Biofilm Matrices of P. fluorescens and E. coli by the Treatment with 2.7 and $10.0 \mathrm{mg} / \mathrm{L}$ of Ozone Water, Respectively, for Indicated Times

The amounts of matrices remained in wells were determined by the crystal violet staining method ${ }^{44,45)}$ as described in Fig. 10. Adsorbed CV on the matrix was eluted with $70 \%$ ethanol and the OD of elute was determined at $595 \mathrm{~nm}$. Remaining ratio of matrix was obtained by dividing OD of treated matrix by those of not-treated. Points and bars represent means \pm S.D. of 3 plates of 16 wells/plate.

成と構成成分について概説し，そして各種酸化性殺 菌剂によるバイオフィルム殺菌の実際，オゾン水と 過酸化水素水との併用によるバイオフィルム殺菌効 果の促進，そしてバイオフィルムマトリックス除去 について，これまで行ってきた研究結果を基に述べ てきた。 これらの研究から酸化性殺菌剤によるバイ オフィルムの殺菌・除去に対して以下のようなこと が明らかとなったと考える。

I. 本研究で用いたバイオフィルムモデルは簡易 な調製法でありながらも, バイオフィルムの特徵を 備えており，CLSM 観察と併せることが可能で, 多様な殺菌剂における作用効果の評価に有効と考え られる。

II. 浮遊細菌を対象とした殺菌効果試験結果を そのままバイオフィルム殺菌に適用することはでき ない. バイオフィルム形成による抵抗性の増加はマ トリックスや含有成分と酸化性殺菌剂との反応によ り殺菌剤濃度が減少し, 浸透阻害が生じ, 深部への 到達に時間を要することが考えられる。酸化力が高 いオゾンや次亜塩素酸などではこの影響が強く，む しろ酸化力が弱いとされるクロラミン $\left(\mathrm{NH}_{2} \mathrm{Cl}\right)$ や ブロムクロラミン $(\mathrm{BrClNH})$ などにおいては浸透 阻害は小さく, 持続したバイオフィルム殺菌効果を 示すと考えられた。

III. バイオフィルムマトリックスの除去には殺 
菌に比べて高濃度のオゾンや $\mathrm{HClO}$ が必要であっ た. またバイオフィルムマトリックス構成成分の違 いにより，影響をうけることが示された。

IV. 殺菌・除去においては濃度に頼るだけでな $<$, 酸化性殺菌剂の連続暴露などの有効手法開発の 可能性が示唆された。

今後は，形成したバイオフィルムの殺菌除去だけ でなく，その形成の予防や伸展を遅らす検討がさら に重要となり，オゾンを始めとする環境残留性の小 さい酸化性殺菌剂の応用利用が期待される.

謝辞 本稿の終わり際して, 塩素等の酸化剤に よる水の消毒作用の研究への道を開いてくださった 故澤村良二先生，バイオフィルムへの応用研究を示 唆くださった岡田昌二先生, 多くの助言と励ましを 頂いた諸先生方，そしてともに研究に携わってくだ さった学生の方々に深く感謝いたします。また, 研 究の場を与えてくださった日本大学薬学部, 並びに 本稿執筆の機会を与えてくださった日本薬学会に深 く感謝いたします。

利益相反＼cjkstart開示すべき利益相反はない.

\section{REFERENCES}

1) Sutherland I. W., Trends Microbiol., 9, 222227 (2001).

2) Characklis W. G., "Biofilms,"'ed. by Characklis W. G., Marshal K. C., Wiley, New York, 1990, pp. 528-529.

3) Bryers J. D., Biotechnol. Bioengineer., 100, 118 (2008).

4) Costerton J. W., Stewart P. S., Greenberg E. P., Science, 284, 1318-1322 (1999).

5) Tachikawa M., Tezuka M., Sawamura R., Jpn. J. Toxicol. Environ. Health, 39, 202-206 (1993).

6) Tachikawa M., Tezuka M., Sawamura R., Jpn. J. Toxicol. Environ. Health, 39, 297-302 (1993).

7) Tachikawa M., Saita K., Tezuka M., Sawamura R., Jpn. J. Toxicol. Environ. Health, 39, 560-565 (1993).

8) Tachikawa M., Saita K., Tezuka M., Sawamura R., Jpn. J. Toxicol. Environ. Health, 39, 572-576 (1993).
9) Tachikawa M., Matsuno A., Tezuka M., Sawamura R., Jpn. J. Toxicol. Environ. Health, 43, 230-236 (1997).

10) Saita K., Tachikawa M., Tezuka M., Sawamura R., Jpn. J. Toxicol. Environ. Health, 44, 442-450 (1998).

11) Tachikawa M., Sayama C., Saita K., Tezuka M., Sawamura R., Water Res., 36, 2547-2554 (2002).

12) Tachikawa M., Sayama C., Tezuka M., Sawamura R., Seki H., J. Water and Waste, 47, 695-701 (2005).

13) Tachikawa M., Aburada T., Tezuka M., Sawamura R., Water Res., 39, 371-379 (2005).

14) Tachikawa M., Tezuka M., Morita M., Isogai K., Okada S., Water Res., 39, 4126-4132 (2005).

15) Tachikawa M., Yamanaka K., Nakamuro K., Ozone: Sci. Eng., 31, 3-9 (2009).

16) Tachikawa M., Yamanaka K., Water Res., 64, 94-101 (2014).

17) Tachikawa M., Yamanaka K., Proceedings of the 25th Annual Conference on Ozone Science and Technology in Japan, Kyoto, May 2016, p. 166.

18) Characklis W. G., McFeters G. A., Marshall K. C., "Biofilms," ed. by Characklis W. G., Marshall K. C., Wiley, New York, 1990, pp. 341-393.

19) Korber D. R., Lawrence J. R., Lappin-Scott H. M., Costerton J. W., "Microbial Biofilms," ed. by Lappin-Scott H. M., Costerton J. W., Cambridge University Press, Cambridge, 1995, pp. 15-45.

20) O’Toole G., Kaplan H. B., Kolter R., Annu. Rev. Microbiol., 54, 49-79 (2000).

21) Branda S. S., Vik Å., Friedman L., Kolter R., Trends Microbiol., 13, 20-26 (2005).

22) Wimpenny J. W. T., Colasanti R., FEMS Microbiol. Ecol., 22, 1-16 (1997).

23) Walker J. T., Mackerness C. W., Rogers J., Keevil C. W., "Microbial Biofilms," ed. by Lappin-Scott H. M., Costerton J. W., Cambridge University Press, Cambridge, 1995, pp. 196-204.

24) Marsh P. D., "Microbial Biofilms," ed. by Lappin-Scott H. M., Costerton J. W., Cambridge University Press, Cambridge, 1995, pp. 
282-300.

25) Mittelman M. W., "Microbial Biofilms," ed. by Lappin-Scott H. M., Costerton J. W., Cambridge University Press, Cambridge, 1995, pp. 133-147.

26) Taga M. E., Bassler B. L., Proc. Natl. Acad. Sci. USA, 100 (Suppl. 2), 14549-14554 (2003).

27) Camilli A., Bassler B. L., Science, 311, 11131116 (2006).

28) Davey M. E., Caiazza N. C., O’Toole G. A., J. Bacteriol., 185, 1027-1036 (2003) .

29) Pamp S. J., Tolker-Nielsen T., J. Bacteriol., 189, 2531-2539 (2007).

30) Van der Kooij D., Veenendaal H. R., BaarsLoris C., Van der Klift D. W., Drost Y. C., Water Res., 29, 1655-1662 (1995).

31) Flemming H.-C., Appl. Microbiol. Biotechnol., 59, 629-640 (2002).

32) Pedersen K., Water Res., 24, 239-243 (1990).

33) Faille C., Membre J.-M., Ussier J.-P., BellonFontaine M.-N., Carpentier B., Laroche M.A., Benezech T., Biofouling, 15, 261-274 (2000) .

34) Applegate D. H., Bryers J. D., Biotechnol. Bioeng., 37, 17-25 (1991).

35) Schmitt J., Flemming H. C., Water Sci. Technol., 39, 77-82 (1999).
36) Sutherland I. W., Water Sci. Technol., 43, 7786 (2001).

37) Schooling S. R., Beveridge T. J., J. Bacteriol., 188, 5945-5957 (2006).

38) Whitchurch C. B., Tolker-Nielsen T., Ragas P. C., Mattick J. S., Science, 295, 1487 (2002).

39) Molin S., Tolker-Nielsen T., Curr. Opin. Biotechnol., 14, 255-261 (2003).

40) LeChevallier M. W., Cawthon C. D., Lee R. G., Appl. Environ. Microbiol., 54, 2492-2499 (1988).

41) Davies D. G., Chakrabarty A. M., Geesey G. G., Appl. Environ. Microbiol., 59, 1181-1186 (1993).

42) Hoigné J., Bader H., Haag W. R., Staehelin J., Water Res., 19, 993-1004 (1985) .

43 ) U.S. Environmental Protection Agency (EPA), EPA Guidance Manual, “Alternative Disinfectants and Oxidants Guidance Manual," EPA 815-R-99-014, 1999:〈http:// nepis.epa.gov / Exe / ZyPURL.cgi?Dockey = 2000229L.TXT $\rangle$, cited 24 April, 2017.

44) Peeters E., Nelis H. J., Coenye T., J. Microbiol. Methods, 72, 157-165 (2008).

45) Narisawa N., Furukawa S., Ogihara H., Yamasaki M., J. Biosci. Bioeng., 99, 78-80 (2005) . 